\title{
MERGERS AND ACQUISITIONS IN THE GREEK BANKING SECTOR ADDRESSING THE PROFITABILITY QUESTION
}

\author{
Vassilis Chouliaras and Athianos Stergios \\ Department of Accounting, \\ TEI of SERRES, Terma Magnisias 621 24, Greece
}

Received 2013-01-29, Revised 2013-03-25; Accepted 2013-06-20

\begin{abstract}
The wave of mergers and acquisitions of financial institutions which was observed in the United States and Europe in the 1980s and 1990s seems to have affected the Greek banking market by the end of the 1990s. The result was the emergence of new significant players in the market. Despite the fact that scale economies should lead to the improvement of their efficiency, this fact was not confirmed by empirical research and, moreover in several cases there has been an adverse effect. We are focus on financial statement analysis by examining the profitability and performance ratios. Mergers and acquisitions in the Greek banking system contributed to an increase in profitability of banks but they did not lead to improvement to their efficiency. It is an undeniable fact that the development and expansion of banks had a positive effect on the markets, resulting in the attraction of new capital which improved their capital sufficiency and of course on their extroversion, their internationalization and their successful expansion to other markets-particularly to Balkan countries.
\end{abstract}

Keywords: Banking System, Mergers and Acquisitions, Profitability, ROE, ROA

\section{INTRODUCTION}

The term merger refers to the integration of the requirements and the obligations of one or more banks into an existing one or into a new entity. It is evident that the balance sheet of the new institution will be the aggregate of the balance sheets of the enterprises merged.

The term acquisition refers to the transfer of the total or a major part of a bank's shares, on condition that its manageability is confirmed. Following the acquisition comes the absorption (which can be implemented in various ways, such as equity exchange, delivery of transferred shares of the acquiring bank to its shareholders) without it being necessary. It is also possible that the two institutions continue to operate as before, covering different parts of the market, with geographical or other distribution. A common result in both cases is the creation of a larger organization or a group.

Nevertheless, there is an adverse process to that of mergers and acquisitions, the so called, divesting, Corresponding Author: Vassilis Chouliaras, Department of Accounting, types of which are sell-offs, spin-offs, split-offs, splitups and liquidation.

Regarding to the usefulness and effectiveness of Mergers and Acquisitions, two opposing theories have been formulated (Travlos, 1993).

\subsection{The Structural Theory and the Theory of Dynamic Competition}

According to the first, Mergers and Acquisitions overturn the conditions of perfect competition thus preventing it from functioning and resulting to the increase in prices and production being affected negatively. According to the second, the anti-monopoly measures decrease the productivity of enterprises as well as of the economy altogether.

The objectives of Mergers and Acquisitions which lead to bank concentration are not only the increase in the value of shares, because of improvements in productivity or exploitation of monopoly conditions EI of SERRES, Terma Magnisias 621 24, Greece Tel: +302321049175 
which are created in this way, but also the improvement of the position of managerial staff through gaining more authority, influence and power (Berger et al., 1999)

The factors which determine whether a company is attractive to be the target of an acquisition are the following (Katsanis, 1987):

- A low ratio of Price value to Book Value (P/BV). Book Value is the quotient of dividing "Net Position" by the number of shares (net position is the difference between assets and actual liabilities)

- A low rate of the indicator of profits multiplier P/E (Price/Earning per share)

- The existence of considerably undervalued assets in the financial statements

- High liquidity or an increased capability of borrowing

- Signs of a sharp increase in turnover and profits

- Weak managerial team, conflicts, inflexibility and difficulty in decision making

\section{MATERIALS AND METHODS}

\subsection{Mergers and Acquisitions in Practice}

The greatest wave of mergers and acquisitions took place in the early 1990s, while by the end of the decade their number decreased considerably (33\% in OECD countries), mainly because of the corresponding decrease in European countries $(62 \%$ decrease in Germany, 68\% decrease in France, $47 \%$ decrease in Italy, $61 \%$ decrease in Great Britain) and a lesser decrease in the USA (13\%). In contrast to their number, the value of acquisitions increased by $45 \%$ in the USA and $189 \%$ in Great Britain (IMF, 1997).

\subsection{Examples in European Countries}

Netherlands: Merger of Algemene Bank Netherland $(\mathrm{ABN})$ with Amsterdam-Rotterdam Bank (AMRO). Also, merger of the Insurance Company Nationale Nederlanden with Post Bank and resulting in the establishment of the gigantic financial institution International Netherlanden Group (ING).

Spain: Merger of Banco Bilbao with Banco Viscaya, of Caja de Barcelona with La Caixa and finally of Banco Central with Banco Hispano.

Italy: Credito Italiano with Banca di Roma.

Germany: The target of German banks was mainly their inter-state strengthening with Deutsche Bank supporting its subsidiary with Morgan Grenfell in England and respectively Dresner Bank with the English investing company Kleinwort Benson Group but also their strengthening in the domestic market with Bayerisch acquiring Hypotheken Bank.

Undoubtedly, one of the greatest mergers took place in Switzerland between the Union Bank of Switzerland and Swiss Bank Corporation (Karaindros, 1997).

Finally, in Japan, the Bank of Tokyo merged with Mitsubishi, thus establishing the largest bank in the world. Also, Sumitomo merged with Daiwa and Mitsui merged with Taiyo Kobe. Those mergers took place aiming to reform of the banks' portfolios and to strengthen their capital bases (Santiksis, 1988).

\subsection{The results of Mergers and Acquisitions}

The studies which examine the consequences of mergers and acquisitions are rather controversial. Sherman and Rupert (2006), by using the Data Envelopment Analysis (DEA) for 4 banks, indicated that the then recent mergers had resulted in disappointing yields to shareholders as the deferment of benefits from the reduction of cost in retail stores was crucial. Chamberlain (1998), who examined the results of mergers and acquisitions between 1981 and 1987, came to the same conclusion. Cornet and Tehranivian (1992), as well as Pilof (1996), however, had indicated that there was a positive reaction of yields of shares when mergers were announced in advance, a fact was related to the actual future increase in efficiency.

Piper and Weiss (1974) concluded that from 102 mergers that took place between 1946 and 1964 53\% was in fact not profitable because of the high merger price and the failure of the acquiring companies to increase the efficiency of their new capital. In contrast, Varvel (1975) from a sample of 17 mergers observed that there was an improvement in profits, without, nevertheless, it being significant.

Mergers and acquisitions may lead to a decrease in the number of workers, to the downsizing of a bank's network, to the merger of central services as a result of cost reduction. It is however possible that they cause a decrease in the transactions value and income, which can be indifferent or negative. Altunbas et al. (1997) concluded that when cost reduction is higher than the decrease in the transactions value and income, then efficiency improves. The amelioration of technical efficiency is due to the fact that when a larger size is achieved, then the provision of the most modern technological applications is possible, leading to economies of scale.

According to Berger and Humphrey (1992), who studied mergers and acquisitions in the 1980s and up to 
mid-1990s in the USA, it was proven that they led to reductions in operating costs. In contrast, Rhodes et al. (1997), examining the period after mid-1990s, concluded that there was cost reduction primarily for small banks and only in certain cases for the larger ones.

Regarding to the improvement in terms of profitability due to size Berger and Mester (1992) proved that it was greater for small banks than for the larger ones. In several countries of the European Union, such as in France, Germany, Spain and Italy, Altunbas et al. (1997) concluded that cost decreases in most cases for both, small and large banks. Huizinga (2003), however, concluded that above a certain size, which is not always clearly defined, scale reverse economies of scale may emerge.

In the case of inter-state mergers, Lepetit et al. (2004), studying cases in the European field between 1991 and 2001, indicated that the reaction of the market is greater and more positive due to cost reduction and their increased power. In contrast, in a respective study for the USA covering the period 1988-1995, Barsky and DeLong, (1993) does not confirm the positive results.

Regarding to the redistribution of the market share and its implications, Weston et al. (1990) indicated that the concentration of enterprise power bears no signifince on the profits, as there are still more factors of profit shaping. Mueller (1985) found that mergers acquisitions generally lead to small but visible losses in market shares. Also, by no means must the success of a merger been taken for granted. For instance, the merger of the Royal Bank of Scotland with the National Westminster Bank resulted in a higher value, whereas that of the Credit Suisse with DLJ, a decrease in value (Nanopoulos, 2000).

\subsection{Mergers and Acquisitions in Greece}

Given that during 1990s and more specifically in the period 1995-1999 all over the world two mergers and acquisitions took place every day (Athanasoglou and Brissimis, 2004), this trend swept over the Greek market, with a starting-point, according to Standards and Poor's, the liberalization of banking market.

More specifically, the strategic moves of banks were (Chouliaras, 2009; Athianos et al., 2003).

\subsection{National Bank of Greece}

In 1998 it merged with its subsidiary National Mortgage Bank, which in the previous year had merged with National Housing Bank. In 2002, the National Bank of Greece absorbed its subsidiary the Hellenic Bank of Investment and Industrial Development.

\subsection{Commercial Bank}

The Commercial Bank followed a reverse course. In 1997 , it sold the majority of its block of shares of the Attica Bank to the Engineers' and Public Constructors' Pension Fund (34\%) and that to the Consignment Deposits and Loans Fund (15\%), keeping only $17 \%$ for itself, along with the right of management until 2002. In 1998 , it sold $51 \%$ of its shares of Ioniki Bank to Alphabank. In May 2002, the French bank Credit Agricole acquired $6.7 \%$ of the Commercial Bank's equity (later its participation reached $9 \%$ ).

Alphabank proceeded only to one move of enlargement which established it as the second largest bank in the Greek banking system, when in 1999 it acquired $51 \%$ of the equity capital of Ioniki Bank, one of the 5 largest national banks at the time.

Eurobank Established in 1990 as Euroinvestment Bank, it had six branches until 1996. The initial move towards its enlargement took place in 1996, when Consolidated Eurobank Finance Holdings Ltd, the mother company of Eurobank (whose name was then "Euroinvestment") bought from Bank Worms 95\% of the interbank equity. In 1998 it bought from the Korean Group Hanwa $58.08 \%$ of the ordinary and $51 \%$ of the preferred shares of the Bank of Athens. In June 1998, having acquired 5 out of 7 branches of Credit Lyonnais in Greece in 1997, it proceeded to a most decisive move when it acquired the Bank of Crete From the Bank of Greece. Finally, in 1999, in an aggressive move it gained control of the Ergasias Bank. The new bank, named Eurobank-Ergasias, with the aforementioned moves achieved in becoming an important player in the Greek banking system. In 2001, Eurobank proceeded to the acquisition of investment bank Telesis, which had 5 branches and several subsidiaries mainly in the finance sector, thus further improving its market share.

Bank of Piraeus It was founded in its new form in 1992 after privatization, when the state-owned Commercial Bank sold $66.67 \%$ to a group of private investors. The initial step was small scaled: the acquisition of two branches by Chase Manhattan Corporation. The biggest and most significant move took place in May 1998, when it acquired 36.98\% of the shares of the Macedonia-Thrace Bank from the National Bank of Investment and Industrial Development 
and the Post Savings Bank. In the same period it acquired from National Westminster Bank elements of the assets and liabilities of its central bank and five branches. In September 1998 it proceeded to the acquisition of the assets and two branches of Credit Lyonnais which was converted into an investment bank under the name Piraeus Prime Bank, in which the Bank of Tokyo-Mitsubishi participates. In November 1998, it acquired $37.8 \%$ of Chiosbank. In 2001, it acquired $57.8 \%$ from the Greek State shares of the Greek Bank of Industrial Development (ETBA).

Egnatia Egnatia acquired, after competition with award to the highest bidder held by the Agricultural Bank of Greece, $51 \%$ of ordinary shares and $20.1 \%$ of preferred shares of the Bank of Central Greece.

A turning point in the mergers and an acquisition was when, in October 2001, the merger of National Bank of Greece with Alphabank, two of the biggest commercial banks of the country was announced. The prospect of that merger was the establishment of a banking organization with total assets of approximately 80 billion euros, thus becoming the 23rd in size European Bank concentrating $40 \%$ of deposits of the Greek market and $33 \%$ of all mutual funds. Despite the strong will of the administrators of both banks and the favourable political circumstances, the merger failed, mainly due to problems caused by their high rank executives regarding to the distribution of power and duties.

There were mergers and acquisitions by other minor banks, such as the acquisition of ABN AMRO by Aspisbank in 2002, which resulted in the increase of the network of the latter from 24 to 41 branches, thus increasing its market share to $1.5 \%$, without, however, managing to establish a banking entity of a significant size that would be capable to become a new player in the greek banking market.

\subsection{Studies of Mergers and Acquisitions Consequences to the Productivity and Efficiency of Banks}

The studies concerning the productivity and efficiency of banks over the last decade are associated with mergers and acquisitions only partially. Nevertheless, they deserve to be mentioned as they contain very interesting findings.

Vasileiou (1993), studying the development of the return of equities and assets (ROE and ROA) for the period 1982-1991 and using a sample of 12 banks, came to the conclusion that ROE and ROA in the period 1982-
1987 were increasing and in the period 1987-1991 they exhibited a sharp increase.

Staikouras and Steliaros (1999), examining factors of profitability concluded that the size of the bank exerts smaller influence on profitability.

Noulas (1999) studied the profitability of banks in the period 1993-1998 and concluded that ROA and ROE were neutral or decreasing for the years 1994-1996 while they increased in the years 1997 and 1998. A similar trend was observed for the profit margin ratio.

Eichengreen and Gibson (2001) analyzing the greek banking market over the period 1980-1998, with a sample of 26 commercial banks, concluded that profitability is a non-linear function of the size of the banks. Fotiou (2006) investigating profitability (ROE and ROA) with the use of a linear equation of the type $Y=f(x)$, where $x$ includes various factors like the ratio of the size of a bank, the ratio of the concentration degree of the market, the ratio of capital efficiency (share capital/total assets) concluded that for ROA the variables which were statistically significant and with negative effect are the market share in loan giving, the range of interest rates, the proprietary status and the operating efficiency ratio.

Gibson (2005), studying the same indicators for the period 1980-2004, concluded that they exhibit a downward trend apart from the period 1998-1999, when there was an upward trend in the stock exchange (there were sales and repurchase of shares and mediation in stock exchange transactions)

For the period 1993-1999, Kamberoglou et al. (2004) found that the Greek banking system is characterized by considerable cost inefficiencies. Technological development had a serious effect on the improvement in efficiency of banks.

The correlation between efficiency and mergers and acquisitions was tested only by Assimakopoulos et al. (2008) in a study carried out by means of Data envelopment analysis for the period 1994-2006, in which they concluded that banks improved their efficiency by $8 \%$. For the period 1998-1999, there was a decline in efficiency because in the mergers and the acquisitions of that period the most efficient banks acquired the less efficient ones.

\section{RESULTS}

The curve of development of the National Bank of Greece is bell-shaped with considerable increase in the period 1998-2001 and a mild decline afterwards. The 
same rule applies to the Commercial Bank of Greece but the main characteristic in this case is the sharp decline to the point of negative efficiency. In the Agricultural Bank of Greece a decline is observed after 2001, which, nevertheless, is withheld and eventually efficiency increases. The situation in Piraeus Bank is similar. In Alphabank, however, which, as a mentioned was particularly active in the field of mergers and acquisitions, despite the fact that there appears a spate of profitability, the decline is evident by the end of that period. Finally, in Eurobank there are fluctuations which cannot be described as normal.

While definite conclusions cannot be drawn regarding the effect of mergers and acquisitions on ROE development, it appears that ROA development is better suited for comparisons and conclusions.

In particular, in the case of the National Bank of Greece the improvement is observed if the 1999 spate is not taken into account. However, the rate of its improvement, as is drawn from the value of $b$ in the equation $y=a+b x$, where $y$ is ROA and $x$ is total assets, declines after the period of the aforementioned acquisitions. This development cannot be interpreted from the operating efficiency which improves, albeit not stably, but the total efficiency which shows fluctuations and, in particular, in corresponding linear regression the correlation factor in the latter period is definitely smaller than the respective one of the former and the value of $b$ in the same periods 3 and 140, because the value of $b$ in the regression of profits by the total assets is 0.0093 and 0.0171 respectively. It is obvious that the mergers and acquisitions did not lead to the improvement of efficiency in the National Bank of Greece, due to the nature of loans of the National Mortgage Bank and those of the National Housing Bank: mortgages have a lower spread than consumer loans which gradually replaced business loans in the National Bank of Greece and are less likely to attract the so called productive job holders.

In Alphabank, in the period following the mergers and acquisitions ROA is definitely inferior (approximately by half) compared to that of the former period. Factor $b$ in the regression of ROA by the total assets of the first phase is negative $(-0.73)$ whereas that of the second phase is positive (0.053). The first approach to the interpretation of this development is that mergers and acquisitions had a positive effect on the efficiency of the assets of the bank. However, if we take into account the fact that factor $b$ in the ratio of profits to total assets in the first phase is twice as high as that of the second phase (0.0237 compared to 0.0137), the conclusion is contradictory. Moreover, if we observe that total efficiency, despite the fact that in the second phase is rather higher with an average of 1.37 than that in the first phase (1.19 on average), has a lower growth rate in relation to the assets and that the operating efficiency decreases in proportion to the increase of assets (factor $b$ in the equation of operating efficiency to total assets at a value of -27 as compared to 19 of the first phase), it is obvious that the acquisition of the Ioniki Bank by Alphabank did not contribute to its efficiency improvement. This can be explained because Ioniki, as a state-controlled bank, had not developed modernized organizational systems of its operation and the quality of its loan portfolio was not analogous to that of Alphabank.

Regarding to Eurobank, in the period after the acquisition of the Ergasias Bank, ROA, on average, is similar to that prior to acquisition period. Also, there is no distinct improvement to any ratio, such as the operating and total efficiency and finally, no change is observed in the alteration rates (factor $b$ of the respective regressions) of operating and total efficiency in relation to the total assets or of the profits in relation to the total assets.

Finally, in Pireaus Bank, after the acquisition of the Macedonia-Thrace Bank, ROA seems to have a significant sudden decline, which, however, in time improves, but not at the increasing rate before the acquisition, since factor $\mathrm{b}$ in the regression of ROA by total assets before the acquisition was 3.56 whereas after it was 0.67 and the regression of profits by total assets the value of $b$ is almost three times as high as that before the acquisition. This development can best be explained by the fact that the alteration of total efficiency after the acquisition is negative $(b=-24)$ whereas before the acquisition was positive $(b=72)$.

In contrast, for the two banks which did not participate in the wave of mergers and acquisitions, Agricultural Bank and Commercial Bank, profitability and efficiency during the fifteen-year period show fluctuations which cannot be interpreted and an overall impression of much difference between them? Commercial Bank, in the last five years, is heading for detrimental operation with its total profitability in steady decline. By contrast, Agricultural Bank shows measurable improvement of ROA and total efficiency mainly after 2000 .

\section{DISCUSSION}

For the study of the consequences of mergers and acquisitions to the efficiency of banks, the balance sheets 
of some of the most important banks were taken into consideration (in particular, those of the National Bank of Greece, the Commercial Bank of Greece, the Agricultural Bank of Greece, Alphabank, Eurobank and Piraeus Bank) of the fifteen-year period 1993-2007 and more specifically some factors, such as total assets, equity, profits before taxation, financial income and expenses as well as operating expenses. On the basis of these factors the efficiency of assets use (ROA), the efficient use of equity (ROE), the operating efficiency and the total efficiency were calculated (as they appear in the tables of the appendix).

It is obvious that ROE rates cannot lead to safe conclusions concerning the development of profitability, because the capital raises that occurred for the most part in the 1997-2002 period in almost all of the banks is not suitable for comparisons. However, it is clear that there is an improvement of profitability by the end of the 1990s, which originates from the expansion of profitable sources and more specifically from the upward trend of the stock exchange, the income derived from mediation in foreign currency transactions and the underwriting of bonds.

\section{CONCLUSION}

Mergers and acquisitions in the Greek banking system contributed to an increase in profitability of banks but they did not lead to improvement to their efficiency. On the contrary, in most cases, this efficiency has clearly declined. This can be explained by the fact that the target banks, in most cases, were not particularly efficient, at least to the extent to which the acquiring banks were and mainly because the former were the "weakest links" in the market (with the exception of Ergasias Bank) they became the targets of the acquiring banks. It must be noted that in the two banks which were not involved in mergers and acquisitions the landscape is mixed and opposing.

However, it is an undeniable fact that the development and expansion of banks had a positive effect on the markets, resulting in the attraction of new capital which improved their capital sufficiency and of course on their extroversion, their internationalization and their successful expansion to other marketsparticularly to Balkan countries.

\section{REFERENCES}

Altunbas, Y., P. Molyneux and J. Thorton, 1997. BigBank Mergers in Europe: An Analysis of the Cost Implications. Economica, 64: 317-329. DOI: 10.1111/1468-0335.00080
Assimakopoulos, I., S. Brissimis and M. Delis, 2008. Efficiency of the greek banking system and its defining factors. Econ. Bull. Bank Greece, 30: 7-31.

Athanasoglou, P.P. and S.N. Brissimis, 2004. The effect of mergers and acquisitions on bank efficiency in Greece. Econ. Bull. Bank Greece, 22: 7-31.

Athianos, S., D. Paschaloudis, K. Katrakilidis, A. Karassavoglou and P. Pantelidis, 2003. The impact of mergers and acquisitions: A quality approach. Proceedings of the 3rd International Conference on New Horizons in Industry and Education, Aug. 2829, Santorini, Greece, pp: 594-600.

Barsky, R.B. and J.B. DeLong, 1993. Why does the stock market fluctuate? Q. J. Econom., 108: 291-312.

Berger, A.N. and D.B. Humphrey, 1992. Megamergers in banking and the use of cost efficiency as an antitrust defense. Antitrust Bull., 37: 541-600.

Berger, A.N., R. Demsetz and P. Straham, 1999. The consolidation of the financial services industry: Causes, consequences and implications for the future. J. Bank. Finance, 23: 135-194.

Chamberlain, S.L., 1998. The effect of bank ownership changes on subsidiary-level earnings. Bank Mergers Acquisit., 3: 137-172. DOI: 10.1007/978-1-47572799-9_7

Chouliaras, V., 2009. The greek banking system in the unified European market. Democritus University of Thrace.

Cornet, M. and H. Tehranivian, 1992. Changes in corporate performance associated with bank acquisitions. J. Financial Econ., 31: 211-234.

Eichengreen, B. and H. Gibson, 2001. Greek Banking at the Dawn of the New Millennium. 1st Edn., Centre for Economic Policy Research, pp: 41.

Fotiou, C., 2006. Profitability in the greek banking environment: Defining factors. University of Macedonia.

Gibson, H., 2005. Profitability of greek banks: Recent facts. Econo. Bull. Bank Greece, 24: 7-27.

Huizinga, H., 2003. EMU and Financial Market Structure. In: EMU and Economic Policy in Eurobankbankpe, Buti, M. and A. Sapir (Eds.), pp: 303-333.

IMF, 1997. International Capital Markets: Developments, Prospects and Key Policy Issues. 1st Edn., International Monetary Fund, ISBN-10: 1455269808, pp: 155.

Kamberoglou, N.C., E. Liapis, G. Simigiannis and P. Tzamourani, 2004. Cost efficiency in greek banking. Bank of Greece. 
Karaindros, N., 1997. Mergers and acquisitions in the banking sector. Bulletin of the Union of Greek Banks.

Katsanis, C., 1987. Mergers of enterprises and hostile bids for deed acquisition. Bulletin of the Union of Greek Banks.

Lepetit, L., S. Patry and R. Rous, 2004. Diversification versus specialization: An event study of M\&As in the European banking industry. Applied Financial Econ., 14: 663-669.

Mueller, D.C., 1985. Mergers and market share. Rev. Econ. Statist., 67: 259-267.

Nanopoulos, N., 2000. International trends in banking mergers and acquisitions and possible implications on the banking sector of SE European countries. Bulletin of the Union of Greek Banks.

Noulas, A., 1999. Profitability and efficiency of Greek Banks 1993-1998. Bulletin of the Union of Greek Banks.

Pilof, S., 1996. Performance changes and shareholder wealth creation associated with mergers of publicly traded banking institutions. J. Money Credit Bank., 28: 294-310.

Piper, T.R. and S.J. Weiss, 1974. The profitability of multibank holding company acquisitions. J. Finance, 29: $163-174$. DOI: $10.1111 / \mathrm{j} .1540-$ 6261.1974.tb00032.x
Rhodes, N.P., J.A. Hunt, and D.F. Williams, 1997. Macrophage subpopulation differentiation by stimulation with biomaterials. J. Biomed. Mater. Res., 37: 481-488. DOI: 10.1002/(SICI)10974636(19971215)37:4<481::AID-JBM6>3.0.CO;2-H

Santiksis, D., 1988. EMU, banks and financial products. Bulletin of the Union of Greek Banks.

Sherman, D. and T. Rupert, 2006. Do bank mergers have hidden or foregone value? Realized and unrealized operating synergies in one bank merger. Eur. J. Operat. Res., 168: 253-268. DOI: 10.1016/j.ejor.2004.05.002

Staikouras, C. and M. Steliaros, 1999. Defining factors of profitability of greek banking institutions.

Travlos, 1993. Mergers and Acquisitions of enterprises. Bulletin of the Union of Greek Banks.

Varvel, W., 1975. A valuation approach to bank holding company acquisitions. FRB Richmond Econ. Rev., 61: 9-15.

Vasileiou, D., 1993. Expansion of profitability of the Greek banking market. Bulletin of the Union of Greek Banks.

Weston, J.F., K.S. Chung and S. Hoag, 1990. Mergers, Restructuring and Corporate Control. 1st Edn., Prentice Hall, ISBN-10: 0135771722, pp: 762. 